\title{
Gold Nanoparticles Targeting Human Cervical Cancer Cells
}

Hayat Awadh Merkadh ${ }^{*}$, Fatimah Mezaal Hameed

Al-Diwaniya Maternity and Child Teaching Hospital, Al-Diwaniya Province, Iraq

DOI: 10.36348/sijog.2019.v02i12.003 $\quad$ | Received: 01.12.2019| Accepted: 15.12.2019| Published: 22.12 .2019

*Corresponding author: Dr. Hayat Awadh Merkadh

Abstract

The most disturbing gynecologic malignancies are cervical cancer particularly in the developing world with the same high incidence in Iraqi women. Cervical carcinoma has a high rate of mortality. The high death rate is associated with presence of human papillomavirus (HPV) infection. Cervical carcinoma is hard to treat, and conventional therapies are very aggressive which lead for the need for new approaches of therapy. Nanoparticles is a promising treatment modality to produce non-toxic and efficient cancer therapy. Gold nanoparticles (AuNPs) accumulate in cancer cells selectively. The current work was aimed to study cytotoxicity and cell death induced by AuNPs on cervical carcinoma cells. Methods: Cytotoxicity of AuNPs was assessed by MTT viability assay and analysed using multiple comparison ANOVA tests. Results: AuNPs nanoparticles from 12.5 up to $50 \mu \mathrm{g} / \mathrm{mL}$ for 72 hours showed concentration-dependent killing activity. Conclusion: Gold nanoparticles have anti-cervical carcinoma cells activity by cell death induction.

Keywords: Gold nanoparticles (AuNPs), cytotoxicity. Cell death, cervical cancer, Hela cells.

Copyright @ 2019: This is an open-access article distributed under the terms of the Creative Commons Attribution license which permits unrestricted use, distribution, and reproduction in any medium for non-commercial use (NonCommercial, or CC-BY-NC) provided the original author and source are credited.

\section{INTRODUCTION}

The most disturbing gynecologic malignancies is cervical cancer particularly in the developing world [27]. The new cervical cancer cases are about 569,847 diagnosed annually worldwide (estimates for 2018) [12]. Human Papillomavirus (HPV) infection is associated with the cervical cancer [23]. In Iraq, cervical cancer ranked 9th most common cancer in Iraqi women aged 15 to 44 years [13]. The most frequent type of cervical cancers is squamous cell carcinoma (SCC) which is about 85\% [11]. There are known risk factors associated with cervical cancer in addition to HPV infection, such as cigarette smoking and smoke carcinogen (benzo[a]pyrene, BaP) [7]. Human papilloma virus (HPV) subtypes that cause cancer is genotype 16 that cause SCC and genotype 18 that cause adenocarcinoma [25]. It is well reported the importance of HPV infection in different type of benign and malignant tumors. It is well established that there is association between HPVs with cervical cancer [29]. Moreover, environmental pollutions associated with conflicts may be another source for increase cancer related cases [5]. There were numerous attempts to overcome resistance to conventional therapies to accomplish a considerable therapeutic effect in malignant tumors by using gold nanoparticles [8, 18]. The resistant of cancer while there is treatment for long time, will cause progressive type of malignant tumors, requires the development of novel therapeutic modalities to overcome chemo-resistance and enhance prolong surviving effect [15]. Nanoparticles is a promising treatment modality to produce non-toxic and efficient cancer therapy $[6,26]$. Nanoparticles carry unique chemical and physical features [31], these features utilized in biomedical applications [20] such as cancer [9]. Nanoparticles were combined with other cancer targeting agents to enhance therapeutic effects [6]. The search for more effective therapy is needed, therefore we designed the current study to use Gold (AuNPs) nanoparticles as anti-cervical cancer therapy which hold promise for clinical application.

\section{MATERIALS AND METHODS \\ Maintenance of cell cultures}

The human cervical cancer cell line, Hela were cultured in basic MEM media (Usbiological, USA) supplemented by $10 \%$ fetal bovine serum (FBS), 100 units $/ \mathrm{mL}$ penicillin and $100 \mu \mathrm{g} / \mathrm{mL}$ streptomycin (Capricorn- Scientific, Germany). The cell line is authenticated regularly. Hela cell line was subcultured 
using trypsin-EDTA when confluent monolayer was achieved and incubated at $37^{\circ} \mathrm{C}$ in $5 \% \mathrm{CO} 2$ humidified incubator $[2,4]$.

\section{Gold nanoparticles}

The current work used highly stable gold nanoparticles (AuNPs) of 10nm size, they are designed for biomedical applications [18].

\section{Cytotoxicity determination using MTT assay}

The Hela cells were seeded at concentration of 10000 cells/well in 96 multi-well microplates. The cells were suspended in $10 \%$ FBS MEM medium and allowed to grow for $80 \%$ confluency. Gold NPs were added at several concentrations from 3.2 to $100 \mu \mathrm{g}$ in triplicate and incubated for $72 \mathrm{hrs}$. at the end point, the MTT stain was added at a concentration of $2 \mu \mathrm{g} / \mathrm{ml}$. After $3 \mathrm{~h}$ incubation at $37^{\circ} \mathrm{C}$, Dimethyl Sulfoxide (DMSO) was added to all wells. The measurement of absorbance was done at $580 \mathrm{~nm}$ using biochrom microplate reader. Results of the assay were shown as a percentage of proliferation relative to control cells [1, 3].

\section{STATISTICAL ANALYSIS}

The collected data were statically analyzed using multiple comparison ANOVA tests using GraphPad Prism 6.07; values were presented as the mean \pm S.D of the triplicates.

\section{RESULTS}

\section{Gold NPs suppress Hela cervical cancer cells}

The killing effect of Gold nanoparticles on human cervical carcinoma cells Hela after $72 \mathrm{~h}$ of exposure was shown in figure 1 . The cytotoxicity of GNPs on Hela cervical carcinoma cells was significant in compare to control not treated cells. The GNPs cytotoxicity was significantly elevated with the increase in concentration as shown in table 1. the effective concentrations were $12.5,25$ and $50 \mu \mathrm{g} / \mathrm{ml}$. The results of the cytotoxicity experiment suggest that gold nanoparticles can be valuable anti-cervical cancer therapy. Hela cells treated with AuNPs exhibited detachment and pathological morphological changes. IC50, which is the inhibitory concentration that kills $50 \%$ of the cells, was $8.713 \mu \mathrm{g}$ (Figure-2). The cytopathological changes revealed apoptotic induction in Hela cells when observed under phase contrast inverted microscope. The untreated cells displayed that the cells preserved their unique morphology; most of the untreated cells were attached to the tissue culture plate.

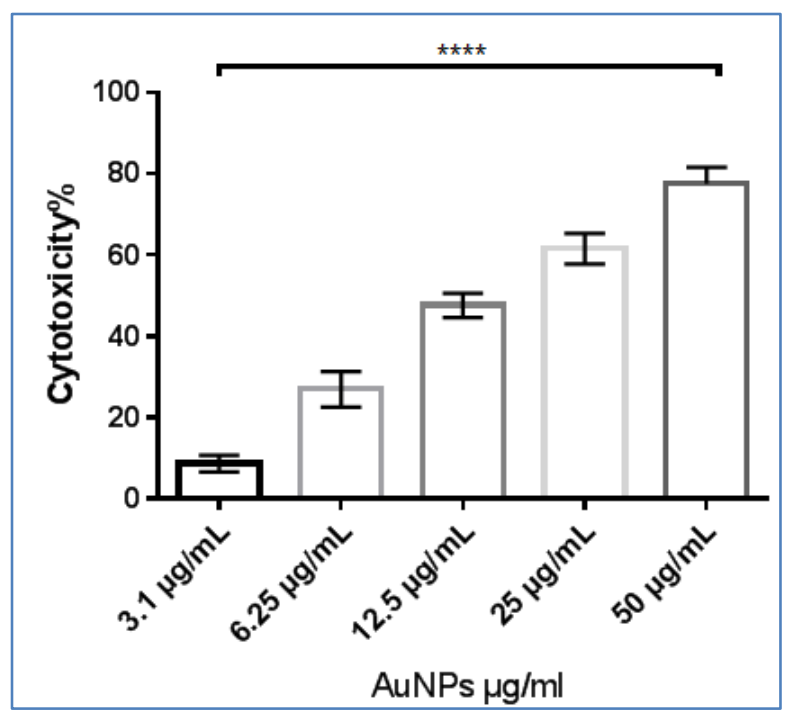

Fig-1: killing effect of gold nanoparticles in cervical cancer Hela cells was measured via the MTT viability assay. The Hela cells were exposed to gold NPs for $72 \mathrm{~h}$ with different concentrations. The effective concentration of AuNPs nanoparticles were from 12.5 to $50 \mu \mathrm{g} / \mathrm{ml}$

Table-1: The cytotoxicity assay effect were analyzed using multiple comparison ANOVA tests

\begin{tabular}{|l|r|r|r|r|}
\hline $\begin{array}{l}\text { Tukey's multiple comparisons } \\
\text { test }\end{array}$ & Mean Diff. & 95\% CI of diff. & Significant? & Summary \\
\hline $3.1 \mu \mathrm{g} / \mathrm{mL}$ vs. $6.25 \mu \mathrm{g} / \mathrm{mL}$ & -18.33 & -27.90 to -8.770 & Yes & $* * *$ \\
\hline $3.1 \mu \mathrm{g} / \mathrm{mL}$ vs. $12.5 \mu \mathrm{g} / \mathrm{mL}$ & -39.00 & -48.56 to -29.44 & Yes & $* * * *$ \\
\hline $3.1 \mu \mathrm{g} / \mathrm{mL}$ vs. $25 \mu \mathrm{g} / \mathrm{mL}$ & -53.00 & -62.56 to -43.44 & Yes & $* * * *$ \\
\hline $3.1 \mu \mathrm{g} / \mathrm{mL}$ vs. $50 \mu \mathrm{g} / \mathrm{mL}$ & -69.00 & -78.56 to -59.44 & Yes & $* * * *$ \\
\hline $6.25 \mu \mathrm{g} / \mathrm{mL}$ vs. $12.5 \mu \mathrm{g} / \mathrm{mL}$ & -20.67 & -30.23 to -11.10 & Yes & $* * *$ \\
\hline $6.25 \mu \mathrm{g} / \mathrm{mL}$ vs. $25 \mu \mathrm{g} / \mathrm{mL}$ & -34.67 & -44.23 to -25.10 & Yes & $* * * *$ \\
\hline $6.25 \mu \mathrm{g} / \mathrm{mL}$ vs. $50 \mu \mathrm{g} / \mathrm{mL}$ & -50.67 & -60.23 to -41.10 & Yes & $* * * *$ \\
\hline $12.5 \mu \mathrm{g} / \mathrm{mL}$ vs. $25 \mu \mathrm{g} / \mathrm{mL}$ & -14.00 & -23.56 to -4.436 & Yes & $* *$ \\
\hline $12.5 \mu \mathrm{g} / \mathrm{mL}$ vs. $50 \mu \mathrm{g} / \mathrm{mL}$ & -30.00 & -39.56 to -20.44 & Yes & $* * * *$ \\
\hline $25 \mu \mathrm{g} / \mathrm{mL}$ vs. $50 \mu \mathrm{g} / \mathrm{mL}$ & -16.00 & -25.56 to -6.436 & Yes & $* *$ \\
\hline
\end{tabular}




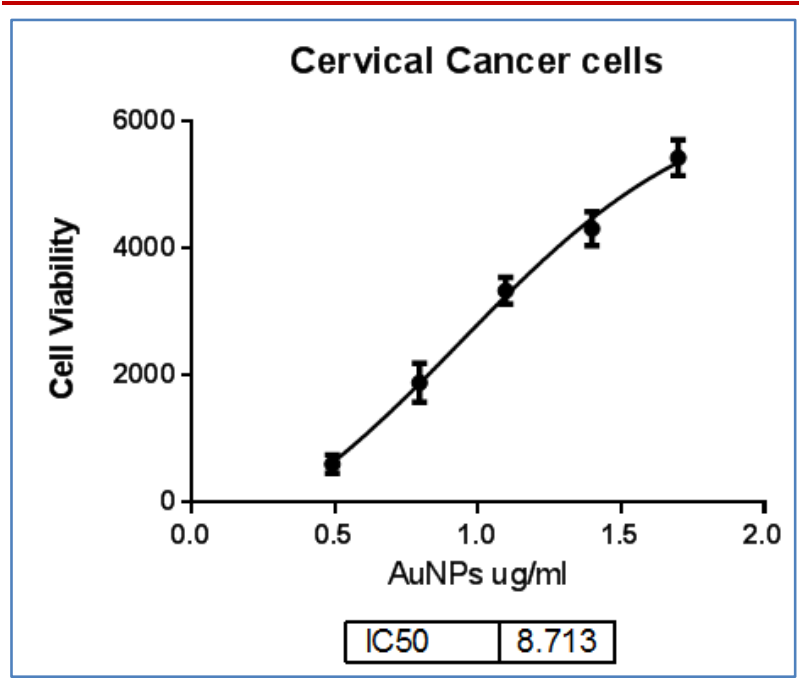

Fig-2: IC50 value for Gold NPs in Hela cells was $8.7 \mu \mathrm{g} / \mathrm{ml}$, this dose reflects sensitivity of cervical cancer cells to nano gold

\section{DISCUSSION}

In the current experiment, the antiproliferative activity of AuNPs nanoparticles to human cervical cancer cells was investigated. Nanoparticles is considered an important drug delivery methods for cervical Cancer treatment [24]. Gold nanoparticles reported to have an anti-cervical cancer properties [19]. The study results showed that AuNPs exposure to cancer cells cause significant cytotoxicity in most doses tested. Gold nanoparticles caused viability reduction in exposed cancer cells. It is reported that biosynthesized gold nanoparticles exposed to Hela cervical cancer cells cause DNA damage, G2/M arrest, and apoptotic cell death via caspase activation [19]. Cell death cytological features of rounding and cell detachment as observed under the inverted microscope. Furthermore, generation of reactive oxygen species (ROS) is enhanced by gold nanoparticles treatment $[8,16]$. Moreover, couple of studies $[10,22]$ showed that $20 \mathrm{~nm}$ gold nanoparticles decrease cancer cells growth mouse model. AuNPs may also used as delivery agents for phytochemicals such as Gallic acid or chemotherapeutic agents such as doxorubicin can be used as replacement for cervical cancer therapy to decrease radiotherapy and chemotherapy side effects [14, 28]. Retinoic acid loaded on gold nanoparticle showed promising anticervical cancer effect [30]. The IC50 dose estimated was $8.713 \mu \mathrm{g} / \mathrm{ml}$ in cervical carcinoma cells. Pharmacokinetic and bio-distribution investigation for AuNPs in tumor bearing animal model showed that gold nanoparticles have high stability when conjugated with therapeutic agents and radiotherapeutic enhancement [17]. Nanoparticles hold very promising activity against cervical cancer [32]. Furthermore, cervical cancer and HPV need to find alternative treatments. Nanoparticles suggested promising in cervical cancer treatment by the capacity to target and internalize cancer cells [21]. In conclusion, the present study proved that gold nanoparticles can be used for cervical cancer therapy.

\section{REFERENCES}

1. Brugnoni, G. C., Di Lorenzo, P. G. C., Didonato, R., Giustiniani, E., Lentini, L., Mariani, M., \& Tami, A. (2017). Islamic Bonds and Real Estate Securitizations: The Italian Perspective for Issuing a Sukuk. In Empirical Studies on Economics of Innovation, Public Economics and Management (pp. 3-28). Springer, Cham.

2. Al-Shammari, A. M., Al-Juboory, A., Asmaa, A., Ali, A. M., Al-Hili, Z. A., \& Yaseen, N. Y. (2014, April). Establishment and characterization of a chemoresistant glioblastoma cell line from an Iraqi patient. In Abstract presented at the 105th Annual Meeting of the American Association for Cancer Research.

3. Al-Shammari, A. M., Ismaeel, F. E., Salih, S. M., \& Yaseen, N. Y. (2014). Live attenuated measles virus vaccine therapy for locally established malignant glioblastoma tumor cells. Oncolytic virotherapy, 3, 57.

4. Al-Shammari, A. M., Alshami, M. A., Umran, M. A., Almukhtar, A. A., Yaseen, N. Y., Raad, K., \& Hussien, A. A. (2015). Establishment and characterization of a receptor-negative, hormonenonresponsive breast cancer cell line from an Iraqi patient. Breast Cancer: Targets and Therapy, 7, 223.

5. Al-Shammari, A. M. (2016). Environmental pollutions associated to conflicts in Iraq and related health problems. Reviews on environmental health, 31(2), 245-250.

6. Al-Shammari, A. M., Zainal, I. G., \& Kachi, W. (2018, May). Oncolytic Virotherapy and Cobalt Ferrite Nanoparticles as Breast Cancer Therapy. In MOLECULAR THERAPY (Vol. 26, No. 5, pp. 345-346). 50 HAMPSHIRE ST, FLOOR 5, CAMBRIDGE, MA 02139 USA: CELL PRESS.

7. Alam, S., Conway, M. J., Chen, H. S., \& Meyers, C. (2008). The cigarette smoke carcinogen benzo [a] pyrene enhances human papillomavirus synthesis. Journal of virology, 82(2), 1053-1058.

8. Ali, Z., Jabir, M., \& Al-Shammari, A. Gold nanoparticles inhibiting proliferation of Human breast cancer cell line.

9. Alsabari, I. K. A., Thahab, S. M., Al-Shammari, A., Saadoon, B. H., \& Allebban, Z. (2017). Nanodrug delivery system as a model for the treatment of breast cancer. The Breast, 32, S28-S29.

10. Arvizo, R. R., Miranda, O. R., Thompson, M. A., Pabelick, C. M., Bhattacharya, R., Robertson, J. D., ... \& Mukherjee, P. (2010). Effect of nanoparticle surface charge at the plasma membrane and beyond. Nano letters, 10(7), 2543-2548.

11. Bourgioti, C., Chatoupis, K., \& Moulopoulos, L. A. (2016). Current imaging strategies for the evaluation of uterine cervical cancer. World journal of radiology, 8(4), 342.

12. Bruni, L., Albero, G., Serrano, B., Mena, M., Gómez, D., \& Muñoz, J. (2019). ICO/IARC information Centre on HPV and Cancer (HPV 
information Centre). Human Papillomavirus and Related Diseases in China. Summary Report 17 June 2019. 2019.

13. Bruni, L., Albero, G., Serrano, B., Mena, M., Gómez, D., \& Muñoz, J. (2019). ICO/IARC information Centre on HPV and Cancer (HPV information Centre). Human Papillomavirus and Related Diseases in China. Summary Report 17 June 2019. 2019.

14. Daduang, J., Palasap, A., Daduang, S., Boonsiri, P., Suwannalert, P., \& Limpaiboon, T. (2015). Gallic acid enhancement of gold nanoparticle anticancer activity in cervical cancer cells. Asian Pac J Cancer Prev, 16(1), 169-174.

15. Elshimali, Y. I., Wu, Y., Khaddour, H., Wu, Y., Gradinaru, D., Sukhija, H., ... \& Vadgama, J. V. (2018). Optimization of Cancer Treatment through Overcoming Drug Resistance. Journal of cancer research and oncobiology, 1(2).

16. Engelberth, S. A., Hempel, N., \& Bergkvist, M. (2014). Development of nanoscale approaches for ovarian cancer therapeutics and diagnostics. Critical Reviews ${ }^{\mathrm{TM}}$ in Oncogenesis, 19(3-4).

17. Geng, F., Xing, J. Z., Chen, J., Yang, R., Hao, Y., Song, K., \& Kong, B. (2014). Pegylated glucose gold nanoparticles for improved in-vivo biodistribution and enhanced radiotherapy on cervical cancer. Journal of biomedical nanotechnology, 10(7), 1205-1216.

18. Jabir, M. S., Taha, A. A., Sahib, U. I., Taqi, Z. J., Al-Shammari, A. M., \& Salman, A. S. (2019). Novel of nano delivery system for Linalool loaded on gold nanoparticles conjugated with CALNN peptide for application in drug uptake and induction of cell death on breast cancer cell line. Materials Science and Engineering: C, 94, 949-964.

19. Jeyaraj, M., Arun, R., Sathishkumar, G., MubarakAli, D., Rajesh, M., Sivanandhan, G., \& Ganapathi, A. (2014). An evidence on G2/M arrest, DNA damage and caspase mediated apoptotic effect of biosynthesized gold nanoparticles on human cervical carcinoma cells (HeLa). Materials Research Bulletin, 52, 15-24.

20. Kachi, W., Al-Shammari, A. M., \& Zainal, I. G. (2019). Cobalt Ferrite Nanoparticles: Preparation, characterization and salinized with 3-aminopropyl triethoxysilane. Energy Procedia, 157, 1353-1365.

21. Medina-Alarcon, K. P., Voltan, A. R., FonsecaSantos, B., Moro, I. J., de Oliveira Souza, F., Chorilli, M., \& Fusco-Almeida, A. M. (2017). Highlights in nanocarriers for the treatment against cervical cancer. Materials Science and Engineering: C, 80, 748-759.
22. Mukherjee, P., Bhattacharya, R., Wang, P., Wang, L., Basu, S., Nagy, J. A., ... \& Soker, S. (2005). Antiangiogenic properties of gold nanoparticles. Clinical Cancer Research,11(9), 3530-3534.

23. Muñoz, N., Bosch, F. X., De Sanjosé, S., Herrero, R., Castellsagué, X., Shah, K. V., ... \& Meijer, C. J. (2003). Epidemiologic classification of human papillomavirus types associated with cervical cancer. New England journal of medicine, 348(6), 518-527.

24. Ordikhani, F., Erdem Arslan, M., Marcelo, R., Sahin, I., Grigsby, P., Schwarz, J. K., \& Azab, A. K. (2016). Drug delivery approaches for the treatment of cervical cancer. Pharmaceutics, $8(3)$, 23.

25. Schiffman, M., Clifford, G., \& Buonaguro, F. M. (2009). Classification of weakly carcinogenic human papillomavirus types: addressing the limits of epidemiology at the borderline. Infectious agents and cancer, $4(1), 8$.

26. Sharma, H., Kumar, K., Choudhary, C., Mishra, P. K., \& Vaidya, B. (2016). Development and characterization of metal oxide nanoparticles for the delivery of anticancer drug. Artificial cells, nanomedicine, and biotechnology, 44(2), 672-679.

27. Small Jr, W., Bacon, M. A., Bajaj, A., Chuang, L. T., Fisher, B. J., Harkenrider, M. M., ... \& Gaffney, D. K. (2017). Cervical cancer: a global health crisis. Cancer, 123(13), 2404-2412.

28. Tomoaia, G., Horovitz, O., Mocanu, A., Nita, A., Avram, A., Racz, C. P., \& Tomoaia-Cotisel, M. (2015). Effects of doxorubicin mediated by gold nanoparticles and resveratrol in two human cervical tumor cell lines. Colloids and Surfaces B: Biointerfaces, 135, 726-734.

29. Tulay, P., \& Serakinci, N. (2016). The role of human papillomaviruses in cancer progression. $J$ Cancer Metastasis Treat, 2, 201-13.

30. Ye, L., \& Song, Q. (2015). Promising potency of retinoic acid-poly (ethylene glycol)-thiol gold nanoparticle conjugates for cervical cancer treatment. International journal of clinical and experimental medicine, 8(7), 10501.

31. Zainal, I. G., Al-Shammari, A. M., \& Kachi, W. (2018, May). Characterization of the modified nickel-zinc ferrite nanoparticles coated with APTES by salinization reaction. In AIP Conference Proceedings (Vol. 1968, No. 1, p. 030008). AIP Publishing.

32. Zaman, M. S., Chauhan, N., Yallapu, M. M., Gara, R. K., Maher, D. M., Kumari, S., \& Chauhan, S. C. (2016). Curcumin nanoformulation for cervical cancer treatment. Scientific reports, 6, 20051. 